\title{
COVID-19: psychosociological phenomenon and implications for nursing
}

\author{
A COVID-19: fenômeno psicossociológico e implicações para a enfermagem \\ COVID-19: fenómeno psicosociológico e implicaciones para la enfermería
}

How to cite this article:

Ferreira de Almeida RM, Azevedo Queiroz AB, de Assunção Ferreira M, Celestino da Silva R. COVID-19: psychosociological phenomenon and implications for nursing. Rev Esc Enferm USP. 2021;55:e20210123. https://doi.org/10.1590/1980-220X-REEUSP-2021-0123.

D Rosa Maria Ferreira de Almeida ${ }^{1}$

(D) Ana Beatriz Azevedo Queiroz ${ }^{2}$

(iD) Márcia de Assunção Ferreira ${ }^{3}$

(iD) Rafael Celestino da Silva ${ }^{3}$

${ }^{1}$ Universidade Federal do Rio de Janeiro, Escola de Enfermagem Anna Nery, Rio de Janeiro, RJ, Brazil.

${ }^{2}$ Universidade Federal do Rio de Janeiro, Escola de Enfermagem Anna Nery, Departamento de Enfermagem Materno-Infantil, Rio de Janeiro, RJ, Brazil.

${ }^{3}$ Universidade Federal do Rio de Janeiro, Escola de Enfermagem Anna Nery, Departamento de Enfermagem Fundamental, Rio de Janeiro, RJ, Brazil.

\section{ABSTRACT}

The objective was to reflect on COVID-19 as a phenomenon of social representations and its implications for nursing and health. A theoretical-reflective study, guided by the precepts of social representations. Reading of scientific articles and books on social representations and official data on COVID-19 were sources for further analytical analysis in the light of theory. COVID-19 is a psycho-sociological phenomenon as it meets the criteria of relevance and practice, in addition to having an imagery and symbolic dimension that circulates in the mass media. There is a projective dimension of the disease by different social groups. The different daily behaviors express a socio-symbolic logic about the phenomenon. The criteria of relevance and practice, the image about the disease and its symbolic dimension support COVID-19 as a phenomenon of social representations, whose research has the potential to improve effective communication with the population, with a view to adherence to preventive care practices to infection.

\section{DESCRIPTORS}

Coronavirus Infections; Pandemics; Psychology, Social; Nursing. 


\section{INTRODUCTION}

The existence of a new type of coronavirus in Wuhan City, Hubei Province, China, in December 2019, was confirmed in January 2020. The new coronavirus was named Coronavirus 2 Severe Acute Respiratory Syndrome (SARS-CoV-2), responsible for causing coronavirus disease 2019 (COVID-19) ${ }^{(1)}$. SARS-CoV-2 transmission occurs through breathing, but the virus can be identified in stool, urine, rectal swab, and blood samples. The common symptoms of COVID-19 are fever, cough and dyspnea, and myalgia, headache, dizziness and gastrointestinal manifestations may occur. Complications include respiratory failure, heart injury, coagulopathies, shock, liver and kidney damage ${ }^{(2-3)}$. Infected people who are asymptomatic can also transmit the virus ${ }^{(4)}$.

With the high speed of spread of the virus between countries, in January 2020 the World Health Organization (WHO) declared a Public Health Emergency of International Concern the highest level of alert - and, on March 11,2020, as the virus was present in more than 200 countries, COVID-19 has been characterized as a pandemic ${ }^{(5)}$. The number of people infected by the disease evolved rapidly over the five months after its appearance, reaching 25 million at the end of this period. As of July 19, 2021, the world had registered 190,597,409 cases and 4,093,145 deaths ${ }^{(5)}$.

On the national scene, the disease was confirmed on February 26, 2020, later spreading throughout the country. This progression was verified by the fact that, six months after the first case, three million people had become infected and 120 thousand had died ${ }^{(6)}$, which indicated a high mortality rate. A retrospective characterization study of the first 250,000 hospital admissions for COVID-19 in Brazil (March to August 2020) registered in the national reporting system showed that hospital mortality was $38 \%$ overall, $59 \%$ among those admitted to Intensive Care Units (ICU), and 80\% among those who underwent mechanical ventilation. The mean age of hospitalized patients was 60 years, and $72 \%$ used some type of respiratory support (invasive or non-invasive) ${ }^{(7)}$.

A survey carried out with 2,054 patients hospitalized with COVID-19 in 25 Brazilian hospitals from March to September 2020 found that overall and ICU-hospital mortality were $22 \%$ and $47.6 \%$, respectively. The median age of patients was 58 years and $32.5 \%$ of hospitalized patients required invasive mechanical ventilation ${ }^{(8)}$. Currently, the number of cases in Brazil totals 19,391,845 million, with a number of deaths exceeding $540,000^{(6)}$.

Evidence published at Imperial College London brought the main recommended measures for COVID-19 control. Measures included mitigation, which consists of isolating suspected cases and family members to delay the spread of the epidemic and reduce the peak demand for medical care, and suppression, which means combining mitigation measures with social distancing from the entire population, with closing of schools, commerce and universities ${ }^{(9)}$. Another measure recommended by the WHO was the use of masks by the general population when circulating in public environments, in order to minimize the respiratory transmission ${ }^{(5)}$.
In Brazil, with the records of the first cases at the beginning of March 2020, travel and event restrictions and teleworking were established for risk groups. The finding of the state of community transmission of coronavirus nationwide, still in March, led to more restrictive guidelines, including the need for social distancing, closing schools, commerce, limiting public transport and significantly reducing industrial activities. In December 2020, the recommendations for social distancing, as well as for the closing of schools, were maintained, but with the coordinated return of commerce and industry activities in several cities across the country.

This context of widespread threat and the implemented social control measures generated disruptions, uncertainty and panic in the face of the unknown as well as questioned subjects' existential dimension and society functioning ${ }^{(10)}$. This points out that COVID-19 is a phenomenon that goes beyond the physical dimension of affecting people's health, but it is also social. From this perspective, the disruption of social normality showed that COVID-19 reveals individual and collective realities, i.e., behaviors towards this phenomenon express norms, values, positions and social relations ${ }^{(10)}$.

It is, therefore, a controversial, emblematic, conflicting and polymorphic object, capable of being understood by the psychosocial perspective of social representations (SR). This understanding of the phenomenon means understanding it in the social reality, as it is appropriated by subjects in the interface between the individual and the social, and how this appropriation engenders behaviors, therefore, a substrate of norms and social relations ${ }^{(10-11)}$.

SR deal with how people interpret reality, i.e., how they construct explanations for social objects ${ }^{(12)}$. They are conceptualized as common sense knowledge, meaning systems produced from interaction and discourses that circulate in social groups, whose functions are to explain reality, define group identity, guide social practices and justify position taking ${ }^{(12-13)}$.

SR "metabolize" the news that the world presents to us, returning to it in the form of understanding, but also as judgments, definitions, and classifications ${ }^{(12)}$. Strange social objects evoke fear, as they threaten people's sense of order and their sense of control over the world, as they do not know how to act in front of such objects ${ }^{(14)}$.

When new social phenomena are relevant, people appropriate them, which can be identified by conversations about the object of SR, its exposure to mass media and the intense movement of scientific dissemination ${ }^{(12-13)}$. Thus, the interest of groups in an object, the circulation of information among participants for their understanding and the pressure for such groups to take a position (pressure to inference) are indicative of SR formation ${ }^{(12)}$.

In the case of COVID-19, it is a new phenomenon that affects the world population and causes a crisis in public health, whose measures to prevent its spread affect people's lives. Therefore, it has pressured people and groups to participate in this debate and take a position on this issue, in an attempt to explain this object and act on it. Different social groups, according to their ideological position, interests and condition of belonging, circulate information about this object. 
Considering that SR are a means of accessing the symbolic, cultural and practical dimensions of social phenomena ${ }^{(13)}$, reflecting on COVID-19 as a phenomenon of psychosocial knowledge generates possibilities for understanding norms, values and potential rumors and stereotypes that guide people's behavior.

Pandemics are not a recent phenomenon in literature, but currently the COVID-19 pandemic has impacted the economy of countries, mainly due to restrictions on the circulation of people and interruption of the functioning of commerce and industries; overloaded health systems, due to the substantial increase in the demand for care; and generated a race of scientists around the world to discover an effective treatment against COVID-19. In view of this, it is considered necessary to reflect on COVID-19 as a psychosocial object, precisely because it is a new disease that has imprinted changes in daily life with important reconfigurations in the ways of being and relating to people, families and groups of friends in the social environment; therefore, these characteristics portray the social thickness of such a phenomenon.

Demonstrating the existence of the socio-symbolic logic of the disease highlights the need to develop SR studies, from which it will be possible to formulate educational technologies that provide quality information, deconstruct stereotypes and minimize population's fear, enhancing the success of preventive measures implemented by nurses in their health promotion actions.

The objective was to reflect on COVID-19 as a SR phenomenon and its implications for nursing and health.

\section{METHOD}

This is a theoretical-reflective study developed in light of the theoretical precepts of SR, which was built in two stages.

In the first stage, scientific articles and books addressing the fundamentals of SR theory and the characteristics of representational phenomena, in addition to those addressing classical representational research on the emergence of new epidemic phenomena in the field of health, were studied. The Brazilian Ministry of Health and the World Health Organization websites were accessed to collect updated data on the COVID-19 pandemic progression and recommendations of these bodies for prevention and control of the disease.

In the second stage, a theoretical-reflective analysis was carried out taking as a reference the preliminary bibliographic study carried out, establishing the interfaces between COVID-19 and $\mathrm{SR}$, in the defense that it conforms to a representational phenomenon. The construction of reflection sessions was theoretically based on the criteria for identifying SR, its formation processes (objective and anchoring) and concepts of social identity and social practices.

\section{DEVELOPMENT}

\section{Theoretical Elements Indicative Of the Existence of SR ON COVID-19}

SR identification criteria were proposed in order to guarantee the validity and specificity of representation studies, such as functional consensus, relevance, practice, holomorphosis, and affiliation. Not all of these criteria are present in all SR, as there are differences in the structure and function of the representation according to its type ${ }^{(15)}$.

The criterion of functional consensus is that in which the SR has the role of maintaining group unity and identity, guiding interactions and self-categorizations. Relevance refers to the social importance of the object for the social actors that relate to it. The criterion of practice, on the other hand, reveals that the object must be involved in practices, especially those of communication. Furthermore, there must be a correspondence between the representations and practices undertaken by most of the people in the group. As for the criterion of holomorphosis, it is constituted by the fact that the representation has reference to group membership, i.e., SR bring meta-information about the group so that each member would know how the other would behave in a given situation. Finally, the affiliation criterion allows to design the socio-group reality within which the representation exists, being the objective side of the holomorphosis criterion $^{(15)}$.

For the purpose and limits of this reflection, the criterion of social relevance, by the proportion of expression that the phenomenon took on in the media due to the magnitude of the cases and their serious socioeconomic consequences and in people's daily lives, and the criterion of practice by the actions, conduct, ways of acting, communicating and relating that were reconfigured due to the pandemic are pointed out.

Communication plays an essential role in SR formation processes, as it is a vector of language and influences the organization of social thought. Communication exchanges enable the construction of new representations and the consolidation of existing ones ${ }^{(12-13)}$. In this regard, it is noteworthy that in the context of the COVID-19 pandemic, in which measures to contain the progress of the disease imply maintaining social distance, a new sociability, more remote and virtual is evidenced, while the absence of physical contact remains. This results in new communication practices between people on social networks and online platforms in an attempt to maintain proximity ${ }^{(10)}$.

In Brazil, through everyday conversations and online conversations, people express opinions, share information and even false news about the implemented control measures and about changes in their daily lives ${ }^{(11)}$. The unfamiliar generates tensions mobilizes emotions and becomes subject of debate ${ }^{(12)}$. Recent epidemics such as swine flu and Ebola have demonstrated the role of digital media in representing diseases ${ }^{(11)}$.

Therefore, it appears that this unknown object awakens affections in social groups, from which people mobilize to participate in the conversation circuit mediated by such an object according to the implications it brings. This movement results in the construction of a common language that guides communications, peer recognition, fostering the feeling of social belonging $^{(12-13)}$.

Another important aspect that reflects the relevance and practice criteria is the media role in SR formation. In the context of the pandemic, information is provided daily on the number of hospitalizations, availability of beds, infected people and deaths in Brazil and worldwide, in addition to measures to control the disease and its social and economic impacts. In turn, people seek information to appropriate this novelty that circulates in society, 
integrating this knowledge "in a language that allows us to talk about what everyone is talking about"(12:51).

This mass communication is a condition of possibility for SR to be created, forged in the interaction and contact with discourses that circulate in the public space, especially in largescale vehicles that spread ideals and reach social groups, generating debate in the public sphere, from which common sense theories emerge ${ }^{(13)}$.

In this communication process, authors warn against the influences of political positioning as a meaning filter of the COVID-19 pandemic, exemplifying from the speeches of political authorities in the mass media. In Brazil and the United States of America, in particular, whose top leaders adopted at the beginning of the pandemic a denial stance on the severity of the disease and the magnitude of the pandemic, it was found that the speeches of these leaders disseminated expressions that brought feeding meanings to social representations about the origin of COVID-19(10-11). Such expressions, which translated into nominations about the virus, resulted in discrimination, xenophobia and violence, mainly against the Asian population around the world. It is observed that research with a structural approach on coronavirus and the pandemic indicated that the word China emerged due to its strong presence in the social imagination about the origin of the pandemic ${ }^{(16)}$.

This circulation of information denotes an imagery dimension with a strong affective charge, with the potential to guide the way people interpret this phenomenon and guide their social practices. Such images are important to identify SR elaboration processes, as is the case of objectification, which encompasses the figurative dimension of the social object. In SR, anchoring and objectification processes are mobilized when individuals are faced with an unusual and unknown object. Anchoring aims to reduce extraneous ideals to common categories and images, placing them in a familiar context ${ }^{(12)}$.

Through anchoring, a person tries to approach situations that are not known, categorizing the phenomena into already known classes and, from that, giving them meanings from an intelligible context. Through objectification, an imagery dimension is attributed to the object presented for comprehension so that what was unknown becomes something objective, naturalized, taking the outline of reality, with concreteness, palpable. The imagery structure of SR becomes a reading guide and, by functional generalization, a reference theory to understand reality ${ }^{(12)}$.

An example of this, when there is an effort to make something unknown known, it can be seen when, by naming the phenomenon of COVID-19 as communavirus, for instance, it is referred to a classification/anchoring in a political and ideological dimension; therefore, the representation would be based on a symbolic construction of a virus that was "produced" in the laboratory by communists with a view to reaching groups against this political ideology. This interpretation, in turn, refers to behaviors that are not properly based on the biological potential for the spread of the virus, but on actions that seek to face what threatens the group's ideological position, even if they disregard the recommendations of health authorities.

This socio-symbolic logic reveals a possible representation based on a conspiracy theory, already historically accessed by other groups. Conspiracy theories are a defense rhetoric, a form of resistance to the most hegemonic SR disseminated by the mass media. In the case of HIV/AIDS, for instance, it was the theory used by marginalized groups, Africans, homosexuals, Haitians and hemophiliacs, who were attributed the origin of the disease in the Western world, to defend themselves against this dominant discourse. With that, they produced a theory that the disease was manufactured in a laboratory by FBI for biological warfare, a conspiracy to destroy the Third World ${ }^{(14)}$.

In the COVID-19 phenomenon, the rhetoric of a virus created by China in the laboratory has been used by groups that adopt behaviors contrary to the dominant scientific discourse on disease control and that have been held responsible by the media for actions that contribute to its dissemination. Furthermore, this rhetoric reinforces stereotypes in relation to the Chinese, who produce and justify certain rejection behaviors, evidencing the practical dimension of SR. It can be seen here that coping with the virus is imagined not only from the biological and social perspective, but also through the prism of science fiction ${ }^{(10)}$.

As for the images, the figure disseminated by the media of the invisible and mysterious enemy transmitted by air seems to anchor COVID-19 not only as something unknown and incomprehensible, but in the field of secrecy and conspiracy. This understanding from the perspective of the mysterious is favored by uncertainties, scientific misunderstandings, social conflicts ${ }^{(10)}$, which can result in exacerbated behaviors of protection against the virus, anxiety and fear in the population.

\section{Social Groups, Identities and Representations}

In the case of the emergence of new epidemic diseases, especially incurable ones, historically people have answered "Not me, not my group". AIDS, for instance, when emerged in the 1980s as the new epidemic disease, was linked to foreign notions and marginal groups (the others), i.e., homosexuals, drug addicts and women prostitutes. Thus, in 1981, when American physicians identified in five homosexuals a set of symptoms that later came to be called AIDS, they initially called it "gay-related immunodeficiency disease". The media, by transforming this finding into attractive material, associated it with a plague. The new phenomenon was "translated" into the image of a plague that affected marginal groups, the "homosexual plague", a notion anchored in the previous threat of the bubonic plague ${ }^{(14)}$.

Therefore, the risk of contagion and dissemination was projected onto the other (external group), distancing themselves and protecting themselves from the threatening situation. This notion spread and generated several risk behaviors by groups that did not feel threatened by the disease ${ }^{(14)}$. This projective behavior, from the perspective of social psychology, has links with social identity, a subjective phenomenon that highlights the similarity and difference between themselves, the other and other groups ${ }^{(17)}$. Therefore, social identity expresses a psychosocial dimension, a position and a way of being in the world ${ }^{(18)}$, playing an important role in our daily lives, as it guides social relationships with each other from identification and differentiation processes, which mediate the meanings attributed to oneself and to others.

SR contribute to such an identity common to individuals, and it fosters social identifications and differentiations based on affiliation and belonging to a social group. Similarity has 
important consequences in the perception of groups, as the more individuals would identify with a group, the more it would differentiate this group from others. So, the effect of the contrast is manifested by an exacerbation of differences between the categories, in which there is in-group appreciation and out-group devaluation, attributing common traits to it - stereotypes $^{(17)}$.

In the case of changes in the social environment that generate insecurity such as COVID-19, there is an exacerbation of unresolved identity conflicts and tensions, on the basis of which projection into defenseless social groups occurs. This knowledge of the groups that can be targets of projection is built from the collective memory, the scientific community, the mass media and daily conversations ${ }^{(14)}$.

The dominant ideology of society plays an important role in this projection, as it propagates the image of specific groups as its other. So, to have a sense of control over a potentially uncontrollable situation, defensive representations of change such as "Not me, not my group" emerge with projection of fear of collapse into external reality. The defensive position as a means of protection implies the creation of stereotypes and abuse and discrimination, and can be increased in crisis $\mathrm{SR}^{(14)}$.

In the case of COVID-19, this process seems to repeat itself, modulating behaviors. Mass media dissemination, in the discourse of politicians and health authorities, of the presence of the disease and the most serious cases, primarily in risk groups, the elderly and people with the presence of other clinical comorbidities, who became the recipients of the projection by the groups that felt protected from the disease, especially when they sought justifications for non-adherence to measures to prevent and control the disease, such as of social distance, was identified.

Therefore, it is assumed that the link between the disease and the foreign condition ${ }^{(14)}$ may also exist in SR organization about COVID-19 and may reveal stereotypes. Regarding this aspect, it is noteworthy that stereotyped symbolic constructions that project onto the other the risk of contamination can lead people to hide the disease to avoid discrimination, not seeking medical care at the appropriate time, in addition to discouraging the adoption of healthy behaviors, factors that can impact the morbidity and mortality rates of this condition and the stability of health services. These constructions are easily disseminated with information technologies, harming the effective communication of health professionals with the population and the greater success of COVID-19 prevention and control actions.

Another point to highlight is that political positioning has been a cognitive filter for appropriation of information about the pandemic. With this, a clear separation is observed "us versus them" based on social identity, which generates controversial representations ${ }^{(10-11)}$.

There are three types of representations, with three levels of consensus: hegemonic, shared by all members of a structured group; emancipated, when different subgroups build their versions of representation and share them; and polemic, generated in conflicts and social tensions that society as a whole does not share. They are determined by the antagonistic relationships between groups and their identities, representing an intergroup conflict $^{(17)}$.
In Brazil, these antagonistic relations occur considering the country's strong political division. On the one hand, scientists and some government officials defend measures to contain the disease, such as social distancing and wearing masks, based on scientific data, a principle of defense of human life and criticism of economic interests, but on the other hand, opponents of these measures believe in a communist conspiracy, in the disbelief of science, in the defense of the country's economy and autonomy ${ }^{(10-11)}$.

This polarization between social groups indicates two distinct anchorages of COVID-19 based on the belonging group: threat to the population's health, which defends the maintenance of social distance according to the WHO guidelines, with a view to preventing the spread of the disease and the health system overload by increased hospitalizations, with the need for help from the poorest by the government; and threat to the country's economy, which advocates the return of commerce and industrial activities to avoid unemployment, considering that there is an exaggeration about the magnitude of the disease and manipulation of information by the media to cause panic in the population ${ }^{(11)}$.

This exemplifies the intertwining between representations, identities and social practices. The group identity processes guide the construction of meanings about COVID-19, which are expressed in degrees of adherence to disease preventive practices $^{(10-11)}$.

\section{Social Practices About COVID-19 and Implications FOR NURSING}

In the context of SR, social practices refer to actions undertaken by individuals who have a social belonging. Action encompasses the affective, behavioral and cognitive components. The relationships between practices and SR are complex and it is necessary to outline which conditions one determines the other. About this, the theory points out three conditions: the perception that the situation may or may not be reversible; the degree of subjects' autonomy in each specific situation; and the degree of activation of the mobilized affective loads, given the collective memory ${ }^{(19)}$.

It is understood that behaviors are part of an actionrepresentation system, i.e., they are the expression of the symbolic elaboration produced by a social actor. This elaboration gives meaning and coherence to the phenomenon represented and is manifested in action considering social norms and roles. Therefore, it is understood that there is an overlap between representations and social practices ${ }^{(19)}$.

Based on the theoretical premise that COVID-19 is a SR phenomenon, supported by the arguments presented so far, the actions/behaviors visualized in the population's daily life and also reported by the mass media are the social expression of the overlap between representations and practices about this phenomenon. Thus, empirical observations of social reality give clues to these social practices related to the disease itself, the people affected by it or in the face of the recommended measures for its control, such as situations identified in northern Brazil, area of professional practice and investigation of one of the researchers in this article. 
An illustration of practices that portray prejudice was noticed during the notifications of the first cases of COVID-19 in the state of Rondônia, from which the Center for Strategic Information in Health Surveillance teams carried out monitoring actions, guidance on distance and individual follow-up of suspected/confirmed cases and contacts at home. In one of the visits to an individual diagnosed with COVID-19, the family reported that their home had been stoned in an attempt to evict them, after community members learned of diagnosis. It was observed in some social media the circulation of banners created by legal bodies with messages "Do not discriminate/judge those who tested positive for COVID-19, be fraternal, be supportive, do not spread negative comments, prejudice or hurt".

As for adherence to disease control measures, it was observed that individuals who are part of certain social groups did not adopt the health recommendations of social distancing, especially when they did not fit into the so-called risk groups established by the scientific community. This observation reinforced the conjecture that there is a feeling of protection from the disease that causes such people to promote or attend social events that generate agglomerations and that have the potential to spread the disease. In Porto Velho, for instance, when there was still control of the disease in relation to the number of cases and social distancing was already recommended, the media denounced the holding of events with socially prominent people in the region, relating such facts to the increase in the number of cases that occurred in the state in subsequent weeks.

In the case of health professionals, the images published on social media are illustrative of population's positive attitudes of support/appreciation/compassion towards this social group, considering their performance towards COVID-19. Different images corroborate this statement: one of them compares health facilities to a battlefield, in which health professionals work on the war front, protecting the population; in another image, professionals are superheroes who face an enemy (COVID-19) to save the population from the impact of the disease; there are also images that denote solidarity and empathy in relation to the work of professionals in dealing with patient death, professional illness, lack of infrastructure, fear of contamination. Fear of transmission and contagion is one of the affective implications that appears in the SR structure of the new coronavirus. The fear that the virus causes in people is due to the fact that the disease impacts physical health and causes emotional distress ${ }^{(20)}$.

These examples show that, given the discoveries in health disseminated by the mass media, social networks and interpersonal communications, people develop SR to become familiar with something that is strange to them and to know how to act in front of it. Therefore, in the case of COVID-19, a new object with a strange name, of a pandemic nature and which resulted in new social rules, it is worth questioning how individuals have dealt with this extraordinary stranger, how they have become familiar, i.e., how they have been objectified and anchored (named, classified, meaning) ${ }^{(10-11)}$.

The theoretical aspects applied in understanding COVID-19 as a psycho-sociological phenomenon in this reflection provide indications of the possible elements that integrate the field of SR organization on this phenomenon - information, affections, images, attitudes, beliefs, and values. Such indications point to important implications for nursing and health professionals, which are related to the meanings constructed about COVID-19, its expressions in practice and the impacts of these actions in preventing the spread of the disease and, consequently, in controlling the pandemic.

Some of these possible meanings and practices were highlighted in this article, namely: the anchorages of COVID-19 that build SR based on conspiracy theories about the creation of the virus and, in turn, lead to discriminatory behavior and that only seek to protect the group's ideological position; COVID-19's objectifications based on images of something mysterious and uncertain, which build SR marked by people's feelings of anxiety and fear of the disease, which are reflected in protection practices against the virus; the disease's projective behaviors in groups considered more vulnerable, which result in the creation of stereotypes, generate a feeling of protection about the disease and less adherence to practices to prevent its spread; the identity filters (political, ideological, normative) used by groups in COVID-19 appropriation within a context of social tension, which produce controversial SR and intergroup conflicts.

Therefore, such theoretical elements reveal clues about how people are appropriating and interpreting knowledge about the disease and how they are dealing with it in their daily lives. Therefore, they help to understand why the deliberate nonadherence to what technicians and scientists recommend to avoid contamination, an aspect that is essential for thinking about the actions of nursing and other health professionals.

Thinking about change based on SR research is to look for the point at which the course of action develops in a different sense. To propose this change, the interest of the object for the group and its immediate context is considered, but also resorting to the past and future, which provide repertoires to give meaning to experiences ${ }^{(12)}$. Therefore, to change actions that do not favor COVID-19 control, it is important to identify SR organization, a place where the meanings, knowledge and information about the phenomenon are structured, thus guiding actions ${ }^{(12-13)}$.

In this understanding, nurses and other health professionals, when knowing the constituent elements and the logic of knowledge of social groups about COVID-19 through their representations, can use contents and schemes that better translate the knowledge of science to modify elements present in the SR organization and allow new objectifications and anchors that favor and promote health care.

As seen, SR are interpretations of reality and are formed in communication and everyday relationships. In the case of COVID-19, such representations feed on the rich raw material that science offers in the many information that circulate in different media about the disease, the sick, the forms of contagion, its consequences and a whole relearning of practices on how to deal with people so as not to become infected.

Therefore, the construction of educational technologies aimed at communication with the population can be instructed with elements that reinforce the representations that produce preventive practices and deconstruct those that put groups at risk, based on the language of the group itself. This has the potential to help people reframe ideas that can generate fear, produce stigmas and stereotypes in relation to the disease as well as lead to risk behaviors that impact on coping actions. 
These considerations portray the potential of SR research for health and, in particular, for nursing, as they favor professionals to better conduct care in a therapeutic plan closer to the logic of the other for whom the care is intended ${ }^{(20)}$. Such research on COVID-19's SR in nursing is still restricted at the national level ${ }^{(21)}$, which requires development, as the results may support, within the scope of SUS, nurses' actions in health promotion.

Periods of epidemics are significant in order to perceive the recurrence of representations, bringing to light conceptions rooted in the social imagination, such as the plague with ideas of death, punishment and scourge ${ }^{(22)}$. Therefore, research contributions are expected to unveil the structure and constituent elements of SR on COVID-19, with a view to elucidating the existence of stereotypes and stigmas that support these representations and imply in the social practices of people facing COVID-19.

The limitations are theoretical, related to the scope of the framework itself, which constitutes one of the possibilities for understanding the COVID-19 phenomenon and understanding its expression in social reality, among other existing perspectives.

\section{CONCLUSION}

The reflection of COVID-19 as a SR phenomenon was supported by the following theoretical arguments: it meets the SR relevance and practice criterion, as it awakens affections that trigger individuals' and social groups' discussions and positions. With that, this phenomenon mobilizes information circulation in the sphere of social relations. The meanings and images about COVID-19 conveyed by the mass media contribute to $\mathrm{SR}$ elaboration processes. There is a projective dimension of the disease in other belonging groups based on social identity. The different behaviors of the population express a socio-symbolic logic that guides social practices.

Health and nursing, by using this theoretical perspective to understand COVID-19, as well as adherence and non-adherence to infection preventive care practices, can develop interventions that reconstruct meanings and practices that compromise the pandemic control, in addition to improving communication with the population. This can reduce fear, anxiety and deconstruct disease-related stigma.

\section{RESUMO}

Objetivou-se refletir sobre a COVID-19 como fenômeno de representações sociais e suas implicações para a enfermagem e a área da saúde. Estudo teórico-reflexivo, orientado pelos preceitos das representações sociais. Leitura de artigos científicos e livros sobre representações sociais e dados oficiais sobre a COVID-19 serviram de fontes para o aprofundamento analítico à luz da teoria. A COVID-19 se configura como fenômeno psicossociológico, porque cumpre os critérios de relevância e de prática, além de ter uma dimensão imagética e simbólica que circula nos meios de comunicação em massa. Verifica-se uma dimensão projetiva da doença por diferentes grupos sociais. Os diferentes comportamentos cotidianos expressam uma lógica sociosimbólica sobre o fenômeno. Os critérios de relevância e prática, a imagem sobre a doença e sua dimensão simbólica sustentam a COVID-19 como fenômeno de representações sociais, cujas pesquisas têm o potencial de melhorar a comunicação efetiva com a população, com vistas à adesão às práticas de cuidado preventivas à infecção.

\section{DESCRITORES}

Infecções por Coronavírus; Pandemias; Psicologia Social; Enfermagem.

\section{RESUMEN}

E1 objetivo fue reflexionar sobre el COVID-19 como fenómeno de las representaciones sociales y sus implicaciones para la enfermería y el área de la salud. Estudio teórico-reflexivo, guiado por los preceptos de las representaciones sociales. La lectura de artículos científicos y libros sobre representaciones sociales y datos oficiales sobre COVID-19 sirvieron como fuentes para un mayor análisis analítico a la luz de la teoría. E1 COVID-19 es un fenómeno psicosociológico, porque cumple con los criterios de relevancia y práctica, además de tener una dimensión imaginaria y simbólica que circula en los medios de comunicación. Existe una dimensión proyectiva de la enfermedad por diferentes grupos sociales. Los diferentes comportamientos cotidianos expresan una lógica socio-simbólica sobre el fenómeno. Los criterios de relevancia y práctica, la imagen sobre la enfermedad y su dimensión simbólica sustentan al COVID-19 como un fenómeno de representaciones sociales, cuya investigación tiene el potencial de mejorar la comunicación efectiva con la población, con miras a la adherencia a las prácticas de atención preventiva para infección.

\section{DESCRIPTORES}

Infecciones por Coronavirus; Pandemias; Psicología Social; Enfermería.

\section{REFERENCES}

1. Khan S, Siddique R, Shereen MA, Ali A, Liu J, Bai Q, et al. Emergence of a novel coronavirus, severe acute respiratory syndrome coronavirus 2: biology and therapeutic options. J Clin Microbiol. 2020;58:e00187-20. DOI: http://dx.doi.org/10.1128/JCM.00187-20.

2. Gouveia CC, Campos L. Coronavirus Disease 2019: clinical review. Acta Med Port. 2020;33(7-8):505-11. DOI: http://dx.doi.org/10.20344/ amp.13957.

3. Neto ARS, Carvalho ARB, Oliveira EMN, Magalhães RLB, Moura MEB, Freitas DRJ. Symptomatic manifestations of the disease caused by coronavirus (COVID-19) in adults: systematic review. Rev Gaúcha Enferm. 2021;42(Suppl):e20200205. DOI: http://dx.doi.org/10.1590/19831447.2021.20200205.

4. Yanes-Lane M, Winters N, Fregonese F, Bastos M, Perlman-Arrow S, Campbell JR, et al. Proportion of asymptomatic infection among COVID-19 positive persons and their transmission potential: A systematic review and meta-analysis. PLoS ONE. 2020;15(11):e0241536. DOI: http://dx.doi. org/10.1371/journal.pone.0241536.

5. World Health Organization. Coronavirus disease (COVID-2019) situation reports [Internet]. Geneva: WHO; 2020 [cited 2021 July 19 ]. Available from: https://www.who.int/emergencies/diseases/novel-coronavirus-2019/situation-reports/.

6. Brasil. Ministério da Saúde. Covid-19 no Brasil [Internet]. Brasília; 2021 [cited 2021 July 19]. Available from: https://covid.saude.gov.br/. 
7. Ranzani OT, Bastos LSL, Gelli JGM, Marchesi JF, Baião F, Hamacher S, et al. Characterisation of the first 250000 hospital admissions for COVID-19 in Brazil: a retrospective analysis of nationwide data. Lancet Respir Med. 2021;9(4):407-18 DOI: http://dx.doi.org/10.1016/ S2213-2600(20)30560-9.

8. Marcolino MS, Ziegelmannb PK, Souza-Silva MVR, Nascimento IJB, Oliveira LM, Monteiro LS. Clinical characteristics and outcomes of patients hospitalized with COVID-19 in Brazil: Results from the Brazilian COVID-19 registry. Int J Infect Dis. 2021;107:300-10. DOI: http://dx.doi. org/10.1016/j.ijid.2021.01.019.

9. Ferguson NM, Laydon D, Nedjati-Gilani G, Imai N, Ainslie K, Baguelin M, et al. Impact of non-pharmaceutical interventions (NPIs) to reduce COVID-19 mortality and healthcare demand. Imperial College London. 2020 Mar:1-20. DOI: http://dx.doi.org/10.25561/77482.

10. Apostolidis T, Santos FS, Kalampalikis N. Society against Covid-19: Challenges for the socio-genetic point of view of Social Representations. PSR [Internet]. 2020 [cited 2021 Feb 10];29(2):3.1-3.14. Available from: https://psr.iscte-iul.pt/index.php/PSR/article/view/551/470.

11. Justo AM, Bousfield ABS, Giacomozzi Al, Camargo BV. Communication, social representations and prevention - information polarization on COVID-19 in Brazil. PSR [Internet]. 2020 [cited 2021 Feb 10];29(2):4.1-4.18. Available from: https://psr.iscte-iul.pt/index.php/PSR/article/ view/533/471.

12. Moscovici S. A psicanálise: sua imagem, seu público. Porto Alegre: Vozes; 2012.

13. Jodelet D. Ciências sociais e representações: estudo dos fenômenos representativos e processos sociais, do local ao global. Sociedade e Estado 2018;33(2):423-42. DOI: http://dx.doi.org/10.1590/s0102-699220183302007.

14. Joffe H. "Eu não, "o meu grupo não": Representações transculturais da AIDS. In: Jovchelovitch S, Guareschi P, organizadores. Textos em representações sociais. Petrópolis: Vozes; 2007. p. 297-322.

15. Wachelke JFR, Camargo BV. Representações Sociais, representações Individuais e comportamento. Interam J Psychol [Internet]. 2007 [cited 2020 June 17];41(3):379-90. Available from: http://pepsic.bvsalud.org/pdf/rip/v41n3/v41n3a13.pdf.

16. Bezerra V, Do Bú E, Alexandre ME, Coutinho MP. Estrutura representacional do novo coronavírus e do estado de pandemia. Psicologia, saúde \& doenças. 2020;21(3):594-605. DOI: http://dx.doi.org/10.15309/20psd210305.

17. Vala J. Representações sociais e percepções intergrupais. Análise Social [Internet]. 1997 [cited 2021 Feb 17];XXXII(140):7-20. Available from: http://analisesocial.ics.ul.pt/documentos/1221840494M6zFQ7xv9Rd55BV5.pdf.

18. Jodelet D. A representação: noção transversal, ferramenta da transdisciplinaridade. Cad Pesqui. 2016;46(162):1258-71. DOI: http://dx.doi. org/10.1590/198053143845.

19. Campos H. O estudo das relações entre práticas sociais e representações: retomando questões. Psicologia e Saber Social. 2017;6(1):42-6. DOI: http://dx.doi.org/10.12957/psi.saber.soc.2017.30664.

20. Ferreira MA. Theory of Social Representations and contributions to the research of health care and nursing. Escola Anna Nery. 2016;20(2):214-19. DOI: http://dx.doi.org/10.5935/1414-8145.20160028.

21. Costa ICP, Sampaio RS, Souza FAC, Dias TKC, Costa BHS, Chaves ECL. Scientific production in online journals about the new coronavirus (covid-19): bibliometric research. Texto \& Contexto Enfermagem. 2020;29:e20200235. DOI: http://dx.doi.org/10.1590/1980-265x-tce-2020-0235.

22. Nascimento DR, Vianna ES, Moraes MC, Silva DSF. O indivíduo, a sociedade e a doença: contexto, representação social e alguns debates na história das doenças. Khronos. 2018;6:31-47. DOI: http://dx.doi.org/10.11606/khronos.v0i6.150982.

Financial support

This study was financed in part by the Coordenação de Aperfeiçoamento de Pessoal de Nível Superior - Brasil (CAPES) - Finance Code 001. 